\section{Professor Hyung Rok YIM, PhD \\ Email: hryim@hanyang.ac.kr \\ School of Business, Hanyang University \\ Seoul, Republic of Korea}

\title{
FIRM PERFORMANCES WITHIN TRANSITION COUNTRIES: PRO-EU GROUP VS. PRO-RUSSIA GROUP
}

\begin{abstract}
Ex-USSR region, so called transition countries, has experienced rapid social and economic transition since the dissolution of USSR in 1991. Owing to the presence of EU (European Union), the region becomes to be highlighted as target countries for inbound FDIs, which weakens their traditional political and economic ties with Russia. Although this trend can cause their economic subordination to $E U$, it is no doubt that institutional transformation to market economy has been contributing to the economic growth of the transition countries. Transition countries are divided into two groups, i.e. pro-EU group and pro-Russia group, and it is fundamentally tackled which group of firms perform better while taking institutional factors into consideration. For this purpose, a game-theoretic model is constructed to scrutinize first if economic transition from communism to free market system becomes to affect firm behaviors in transition countries, second if the performance of firms in pro-EU group dominates that in pro-Russia group, and third, under which mechanism design, firms in the pro-EU group are able to leapfrog incumbents in EU. Empirical findings are to the followings. First, on average, the firm performance of pro-Russia countries turns out to dominate that of pro-EU countries. Second, within transition countries, the firm performance of service sector outweighs that of manufacturing sector. Third, informal payment practice significantly deteriorates the firm performance of pro-EU group. Fourth, the performance of state-owned firms in pro-Russia group is superior to that in pro-EU group. Henceforth, ideally it is desirable for transition countries to reinforce firm-level businesses with EU; however, in practice, it cannot be denied that they are still deeply dependent on Russian economy
\end{abstract}

Keywords: Transition countries, institutional effect, performance, leapfrogging, and behavior.

\section{JEL Classification: P27, P31, L22,O43, 047}

\section{Introduction}

\section{I.1. Background}

In the year of 1991, USSR abruptly collapsed and CEE (Central Eastern Europe) had to experience rapid social and economic transformations from communism toward capitalism. CEE member countries, historically relied on 
HyungRokYim

barter trade, had to find their own ways to survive in the absence of USSR. For the sake of reunion of USSR, Russia led the CIS (Commonwealth of Independent States) in 1991 with eleven member states, i.e., Armenia, Azerbaijan, Belarus, Kazakhstan, Kyrgyzstan, Republic of Moldova, Russian Federation, Tajikistan, Turkmenistan, Ukraine, and Uzbekistan; EAEC (Eurasian Economic Community) participated in CIS. In 2015, EEU (Eurasian Economic Union), pursuing an integrated single market of Eurasia region, was launched to create a new trade bloc.

During transformation periods, those members in CEE, politically tied in USSR under command economy, became to lose integrity each other (Campos and Coricelli, 2002), which brought its dissolution.In 1993, EU was launched and exUSSR countries started to be highlighted as the outbound FDI target countries for the West European firms as globalization drive expands and, accordingly, technology was being primarily transferred to local firms through FDIs during 1990s (Damijan et al, 2003). In the early 2000s, ex-USSR countries have expanded their businesses with EU region while experiencing banking reforms, legal reforms, and corporate governance restructuring. According to Uzagalieva, et al., (2012), MNEs from EU have been regarding firms in transition countries as local suppliers for parts and assembly and thus economic integration, through privatization and liberalization towards EU system, enhances the economic growth of the $e x$-USSR region (Kamau, 2010).

In the paper, those countries in $e x$-USSR region are defined to be transition countries.Transition countries have three distinctive characteristics. First, the economic growth of transition countries owe a lot to DAP (development assistant programs); DAP is designed to introduce free market system, privatization, institutional revolution (Campos \& Horváth, 2012).Nevertheless, transition countries are still deeply tied with Russia because barter trades is sizable ones because transition countries are endowed with abundant natural resources compared to West Europe (Brunnschweiler\&Bulte, 2008). Second, market openness is an impetus to invite inbound FDIs and they increase the employment of transition countries (Bandick\&Karpaty, 2011). Because inbound FDI accelerates privatization move, startups rush to preoccupy niche segments, and even the private subsidiaries of state-owned firms become to explore newer business opportunities. Further, EU trade bloc outweighs Russia, and so local governments in $e x$-USSR region gradually start to adopt pro-EU strategy. Eventually, firms in the region can benefit from EU. Third, another aspect worth mentioning is that the cost inefficiency of banking industry cannot be overlooked within transition countries (Djalilov\&Piessea, 2019). Lack in capital efficiency typically ended in lower innovation in the region, which is a huddle to the economic growth of transition countries. If so, transition countries would be better off maintaining traditional cooperation with Russia but this becomes to prevent them from overcoming the Dutch disease common in the ex-USSR system. 
Firm Performances within Transition Countries: Pro-EU Group vs. Pro-Russia Group

\subsection{Transition Countries}

In the paper, thirty transition countries are classified into either pro-EU group or pro-Russian group. Table 1 provides the list of countries in both groups. A transition country is considered as pro-Russia group if its exports head to Russia the most. Similarly, pro-EU group are those transition countries that export to one of EU members the most. Eighteen countries are classified as the pro-EU group and the pro-Russia group has twelve countries. The transition countries in Table 1 are classified into regional blocs. Albania, Bosnia and Herzegovina, Bulgaria, Croatia, Czech Republic, Hungary, Kosovo, Montenegro, Poland, Romania, Serbia, Slovakia, Slovenia, Macedonia are CEE members while Armenia, Azerbaijan, Belarus, Georgia, Kazakhstan, Kyrgyzstan, Republic of Moldova, Russian Federation, Tajikistan, Turkmenistan, Ukraine, Uzbekistan are CIS members. This simple dichotomy is consistent to previous studies; the CEE countries show similar business cycles with EU while other transition countries show idiosyncratic business cycles (Artis, et al., 2008; Fidrmuc\&Korhonen, 2006).

Table 1. Transition countries

\begin{tabular}{|c|c|c|c|c|c|}
\hline \multicolumn{6}{|c|}{ Pro-EU Economies (18 countries) } \\
\hline Albania & $\begin{array}{c}\text { Italy } \\
(51.1 \%)\end{array}$ & Macedonia & $\begin{array}{c}\text { Germany } \\
(36.9 \%)\end{array}$ & Estonia & $\begin{array}{l}\text { Sweden } \\
(16.8 \%)\end{array}$ \\
\hline Azerbaijan & $\begin{array}{l}\text { Italy } \\
(25 \%)\end{array}$ & Montenegro & $\begin{array}{l}\text { Croatia } \\
(22.7 \%)\end{array}$ & Hungary & $\begin{array}{l}\text { Germany } \\
(25.6 \%)\end{array}$ \\
\hline $\begin{array}{l}\text { Bosnia and } \\
\text { Herzegovina }\end{array}$ & $\begin{array}{c}\text { Germany } \\
(15.6 \%)\end{array}$ & Poland & $\begin{array}{c}\text { Germany } \\
(26 \%)\end{array}$ & Slovakia & $\begin{array}{c}\text { Germany } \\
(22.3 \%)\end{array}$ \\
\hline Bulgaria & $\begin{array}{c}\text { Germany } \\
(10.4 \%)\end{array}$ & Romania & $\begin{array}{c}\text { Germany } \\
(18.9 \%)\end{array}$ & Slovenia & $\begin{array}{c}\text { Germany } \\
(20 \%)\end{array}$ \\
\hline Croatia & $\begin{array}{c}\text { Italy } \\
(14.9 \%)\end{array}$ & Russia & $\begin{array}{c}\text { Netherlands } \\
(14.6 \%)\end{array}$ & & \\
\hline $\begin{array}{c}\text { Czech } \\
\text { Republic }\end{array}$ & $\begin{array}{c}\text { Germany } \\
(31.8 \%)\end{array}$ & Serbia & $\begin{array}{c}\text { Germany } \\
(11 \%)\end{array}$ & & \\
\hline \multicolumn{6}{|c|}{ Pro-Russian Economies (12 countries) } \\
\hline Armenia & $\begin{array}{c}\text { Russia } \\
(19.6 \%))\end{array}$ & Kyrgyzstan & $\begin{array}{c}\text { Russia } \\
(14.6 \%) \\
\end{array}$ & Mongolia & $\begin{array}{l}\text { Russia } \\
(1.5 \%)\end{array}$ \\
\hline Belarus & $\begin{array}{c}\text { Russia } \\
(35.4 \%)\end{array}$ & Latvia & $\begin{array}{l}\text { Russia } \\
(18.2 \%)\end{array}$ & Tajikistan & $\begin{array}{l}\text { Russia } \\
(10.6 \%)\end{array}$ \\
\hline Georgia & $\begin{array}{c}\text { Russia } \\
(6 \%)\end{array}$ & Lithuania & $\begin{array}{c}\text { Russia } \\
(19.8 \%)\end{array}$ & Ukraine & $\begin{array}{l}\text { Russia } \\
(25.6 \%)\end{array}$ \\
\hline Kazakhstan & $\begin{array}{l}\text { Russia } \\
(9 \%)\end{array}$ & Moldova & $\begin{array}{l}\text { Russia } \\
(26.3 \%)\end{array}$ & Uzbekistan & $\begin{array}{l}\text { Russia } \\
(14.7 \%)\end{array}$ \\
\hline
\end{tabular}

1. The numbers in the parentheses are each transition country's export ratio to their top exporting countries.

On average, pro-EU group shows a higher export over total sales ratio compared to pro-Russia group; during 2010s, the average export ratio of the proEU group to its biggest EU partner is around 20\% and that of the pro-Russia group

DOI: $10.24818 / 18423264 / 54.2 .20 .10$ 
HyungRokYim

is around $15 \%$. At a glance, this outcome seems to be parallel to Corden\&Neary (1982)'s early comment that transition countries cannot circumvent the Dutch disease commonly occurring in command economy system. Nevertheless, sharing ex-communism heritage cannot be simply overlooked because strong political and economic ties with Russia, no matter what pro-Russia group's main exports are commodities or not, can play as an important impetus to sustain firm performance.

Acknowledging these environmental circumstances, the main theme of this paper is set to examine what kinds of institutional factors of transition countries affect the performances of their domestic firms. For this purpose, initially, an infinitely repeated game model is constructed in order to explore some important questions. First, it is natural to consider that firms in pro-EU countries are more likely to rely on their businesses with EU region. However, in reality, they maintain strong business relationship with Russian firms as well. Therefore, it should be thoroughly understood by which mechanism they become to maintain two business channels rather than devoting all resources to a larger EU market. Second, a next generic question is whether the firm performance of pro-EU group can outweigh that of pro-Russia group. The game model directly tackles this question. Third, it is scrutinized by which mechanism firms in pro-EU group become to be able to acquire competitive advantages against firms in pro-Russia group. Fourth, it is carefully analyzed if firms in pro-EU group can leapfrog large incumbents in EU market. In terms of mechanism design, it is important to prove how this can happen and whether this event is a sustainable one or not.

Next, empirical frameworks are constructed highlighting following three points. First, it is attempted to explore which group between pro-EU group and pro-Russia group shows superior firm performance. If firms in pro-Russia group turn out to perform better, then one can say that $e x$-USSR regional networking effect can compensate for cost inefficiency in the group. Second, the impact of firm-level characteristic on firm performance is examined affording the impact of institutional factors such as informal payment practice. Third, firm-specific initial foundation type, when it comes to $e x$-USSR region, would have persistent effect on firm performance within transition countries. For instance, firms established as joint venture or foreign subsidiary might show different performances from those established as state-owned company' subsidiary or startup.

The paper is organized as follows. In section 2 , an infinitely repeated transition model is constructed. Pooling ordinary least squares are established in section 3 and section 4 discusses some estimation results. Section 5 summarizes the main findings of the paper along to conclusion remarks.

\section{Model}

\subsection{The Impact of Transition on Firm Performance}

$j$ is a transition country and $i$ is a firm in $j$. Initially, $j$ belongs to a pro-Russia group denoted as $j^{R}$ where the superscript $R$ represents a proRussian group. $j$ can transit from $j^{R}$ to $j^{E} . j^{E}$ represents a pro-EU group. For 
Firm Performances within Transition Countries: Pro-EU Group vs. Pro-Russia Group

transiting to $j^{E}$ successfully, $j$ needs to experience a bridge stage, which is denoted as $j^{R E}$.

The communism-oriented political heritage of $e x$-USSR members plays as an exogenous country factor affecting $i$ 's behavior. Simply, $i$ 's production strategy is set to mix $q^{R}$ and $q^{E}$ according to $\mathrm{q}=\theta q^{R}+(1-\theta) q^{E}$ where $0 \leq \theta \leq 1 . q^{R}$ is a targeted production quantity for Russian market and $q^{E}$ is that for EU market. If $j=j^{R}$, it becomes $q=q^{R}$ with $\theta=1$ and vice versa. If $j=j^{R E}$, then $0<\theta<1$. $\pi_{i}^{j}$ is $i$ 's profit in $j$, which is defined to be (1) where $j \in\left[j^{R}, j^{E}, j^{R E}\right]$. pis a price and $c$ is a marginal cost and so $(p-c)$ represents profit margin.

$$
\pi_{i}^{j}=(p-c)\left(\theta q^{R}+(1-\theta) q^{E}\right)
$$

In a political sense, those transition countries are still in a gray zone because their strong mutual ties with Russian economy cannot be easily replaced by EU even if the pro-EU group can accumulate larger capital quicker than the proRussia group. Awkwardly, this type of structural inefficiency deteriorates free market mechanism across transition countries, which deters $i$ 's performance potentially (White $\&$ Imre, 2013). In that, under $j=j^{R}, i$ has to afford a certain degree of opportunity cost, which defines $i$ 's profit to (2) where $\pi_{i}^{R}$ and $c^{R}$ represent $i$ 's profit and marginal cost when it belongs to $j^{R} . \alpha$ represents $i$ 's opportunity cost originating from $j^{R}$ 's strong political-and-economic tie with Russia $(0 \leq \alpha<1)$.

Doing business with EU firms is a strategic shortcut for $i$ to obtain advanced skills and technologies. To the least, $i$ can learn how to allocate its internal resources at efficient production frontiers. Also, it can achieve a larger scale of production economy relying on the purchasing power of EU trade bloc. $i$ 's profit under $j=j^{E}$ is defined to be (3) where $\pi_{i}^{E}$ represents $i$ 's profit and $\beta$ does an outside option allowed to $i$ when its country transits to $j^{E}(\beta>0)$.

During the bridge stage denoted as $j^{R E}, j$ 's economic system needs to be adjusted to market mechanism whilst $j$ gives up a reciprocal economic tie with Russia. This kind of political transition, which is understood as country factor, would affect $i$ 's performance in both directions; the positive effect of the outside option originating from $j^{E}$ offsets the negative effect of the opportunity cost originating from $j^{R}$. Therefore $i$ 's profit under $j^{R E}$, is defined to be (4). The adjusting factor defined as $(1-\alpha) /(1+\beta)$ prevents $i$ from fully obtaining $\pi_{i}^{E}$ during $j^{R E}$.

$$
\begin{aligned}
& \hat{\pi}_{i}^{R}=(1-\alpha) \pi_{i, t}^{R}=(1-\alpha)\left(p-c^{R}\right) q^{R} \\
& \hat{\pi}_{i}^{E}=(1+\beta) \pi_{i, t}^{E}=(1+\beta)\left(p-c^{E}\right) q^{E} \\
& \hat{\pi}_{i}^{R E}=(1-\alpha) /(1+\beta) \pi_{i, t}^{E}=(1-\alpha) /(1+\beta)\left[( p - c ^ { R } ) \left\{q^{E}+\theta\left(q^{R}-\right.\right.\right.
\end{aligned}
$$

$\left.\left.\left.q^{E}\right)\right\}\right]$

$i$ under $j^{E}$ is exposed to a competitive business environment. In general, $i$ under $j^{E}$ would be more cost efficient compared to $i$ under $j^{R}$ because the transition from

DOI: 10.24818/18423264/54.2.20.10 
$j^{R}$ to $j^{E}$ would invite West European firms' capital investments and FDIs. As long as $j$ stays in $j^{R}, i$ has no choice but to afford cost inefficiency due to inferior production technology as well as social practice and corruption prevailing in $e x$ communism countries. Hence, in the model, it is assumed to be $c^{R}>c^{E}$.

Lemma 1 contains a noteworthy implication. Obviously, $i$ puts a higher weight on $q^{E}$ once $j^{R}$ transits toward $j^{E}$; however, $i$ never abandons $q^{R}$ under $j^{R E}$. A critical reason for keeping this two-track production strategy is fundamentally due toi's long-lasting business relationship with Russian counterparts. In a strategic sense, $i$ 's strategic behavior needs to be understood as a way of diversification; traditional industry sectors between $j$ and Russia are mostly located in primary industries such as mineral, food, raw materials, and agricultural goods. In fact, this aspect is a fundamental driving force for $i$ to transit to $j^{E}$.Lemma 2 exhibits that $i$ 's outside option becomes to enhance its performance. As $j^{R E}$ transits to $j^{E}, i$ can expand its production scale through $q^{E}$ and enhance profitability because $c$ would be lowered.

Lemma 1. Under $j^{R E}, i$ becomes to put more weight on $q^{E}$ than $q^{R}$.

Proof. Under $j^{R}, i$ 's production quantity is limited to $q^{R}$. It is no doubt that $j^{R E}$ can provide better business opportunity to $i$ and thus it is met $\theta q^{R}+(1-$ $\theta) q^{E} \geq q^{R}$; hence, $(1-\theta)\left(q^{E}-q^{R}\right) \geq 0$. Because $0<\theta<1$, it is always $q^{E} \geq$ $q^{R}$. Also, $i$ can produce more under $j^{E}$ rather than under $j^{R E}$, which results in $\theta q^{R}+(1-\theta) q^{E} \leq q^{E}$; hence, $\theta\left(q^{R}-q^{E}\right) \leq 0$. By the same fashion, it is always $q^{E} \geq q^{R}$.

Lemma 2. Under $\beta>0$, it is always $\hat{\pi}_{i}^{R E} \geq \hat{\pi}_{i}^{R}$.

Q.E.D.

Proof. Suppose that $\hat{\pi}_{i}^{R E}<\hat{\pi}_{i}^{R}$, then $\beta>\frac{\pi_{i}^{R E}}{\pi_{i}^{R}}-1$. Because it is $\beta>0$, it should be $\hat{\pi}_{i}^{R E} \geq \hat{\pi}_{i}^{R}$, which is a contradiction. Thus, it is always $\hat{\pi}_{i}^{R E} \geq \hat{\pi}_{i}^{R}$.Q.E.D.

At the meanwhile, it is not directly determined whether $\hat{\pi}_{i}^{E} \geq \hat{\pi}_{i}^{R}$ or not. However, one thing for sure is that, in a relative sense, $i$ 's gains under the transition from $j^{R E}$ to $j^{E}$ dominate its gains under the transition from $j^{R}$ to $j^{R E}$. Thus, (5) holds up. Proposition 1 clearly demonstrates $\hat{\pi}_{i}^{E} \geq \hat{\pi}_{i}^{R}$. Therefore, it is no doubt that the institutional country effect occurred when $j^{R}$ transits to $j^{E}$ directly affects $i$ 's ex post performance.

$$
\frac{\widehat{\pi}_{i}^{E}}{\hat{\pi}_{i}^{R E}} \geq \frac{\widehat{\pi}_{i}^{R E}}{\hat{\pi}_{i}^{R}}
$$
under $j^{R}$.

Proposition 1. The ex post equilibrium profit of $i$ under $j^{E}$ outweighs that

Proof. According to Lemma $2, \pi_{i}^{R E} \geq \pi_{i}^{R}$ where $\beta>0$ and so the upper bound for $\beta$ is restrained to be $\beta \leq \frac{\pi_{i}^{R E}}{\pi_{i}^{R}}-1$. From (5), it is $\hat{\pi}_{i}^{E} \hat{\pi}_{i}^{R} \geq\left(\hat{\pi}_{i, t}^{R E}\right)^{2}$. Given $\hat{\pi}_{i}^{R E} \geq \hat{\pi}_{i}^{R}$, it should be $\hat{\pi}_{i}^{E} \geq \hat{\pi}_{i}^{R}$.

Q.E.D.

DOI: $10.24818 / 18423264 / 54.2 .20 .10$ 
Firm Performances within Transition Countries: Pro-EU Group vs. Pro-Russia Group

Proposition 2 reveals that $i$ 's ex post equilibrium outside option has a nonlinear relationship with $\frac{\pi_{i}^{R E}}{\pi_{i}^{R}}$; initially, $\beta^{*}$ sharply increases when $j$ begins to transit to $j^{E}$. Alternatively stated, $i$ 's posterior performance during $j=j^{R E}$ would be better off as higher the $\beta$ is. In particular, the scale of the outside option expands as the gap between $\pi_{i}^{R E}$ and $\pi_{i}^{R}$ enlarges. This positive impact can create synergy effects across firms in $j=j^{R E}$. This opens a strategic pathway for $j$ to be willing to evolve from $j^{R E}$ to $j^{E}$ because $j$ can achieve a higher economic growth of the country as a whole. $\left(\frac{\pi_{i}^{R E}}{\pi_{i}^{R}}\right)^{\frac{1}{2}}-1$

Proposition 2. $i$ 's equilibrium ex post outside option under $j^{E}$ is $\beta^{*}=$

Proof. Given $\hat{\pi}_{i}^{E} \geq \hat{\pi}_{i}^{R}$, it is $(1+\beta) \geq(1-\alpha)^{\frac{1}{2}}\left(\frac{\pi_{i}^{R E}}{\pi_{i}^{R}}\right)^{\frac{1}{2}}$. Note that the RHS of the upper bound for $(1+\beta)$ is rewritten into $\frac{\pi_{i}^{R E}}{\pi_{i}^{R}}=\left(\frac{\pi_{i}^{R E}}{\pi_{i}^{R}}\right)^{\frac{1}{2}}\left(\frac{\pi_{i}^{R E}}{\pi_{i}^{R}}\right)^{\frac{1}{2}}$. Note that $(1-\alpha) \leq 1$ and $\hat{\pi}_{i}^{R E} \geq \hat{\pi}_{i}^{R}$ by Lemma 2 , which yields $\left(\frac{\pi_{i}^{R E}}{\pi_{i}^{R}}\right)^{\frac{1}{2}}>(1-\alpha)^{\frac{1}{2}}$. Because $\frac{\pi_{i}^{R E}}{\pi_{i}^{R}} \geq(1-\alpha)^{\frac{1}{2}}\left(\frac{\pi_{i}^{R E}}{\pi_{i}^{R}}\right)^{\frac{1}{2}}$, the interval for $\beta$ is derived as $(1-\alpha)^{1 / 2}-1 \leq$ $\beta \leq\left(\frac{\pi_{i}^{R E}}{\pi_{i}^{R}}\right)^{\frac{1}{2}}-1$. $i$ 's best response is to choose $\beta^{*}=\left(\frac{\pi_{i}^{R E}}{\pi_{i}^{R}}\right)^{\frac{1}{2}}-1 . \quad$ Q.E.D.

Proposition 3 demonstrates that $j$ 's strong tie with Russia is negatively related to $i$ 's ex post outside option. For instance, $i$ just wants to enjoy $\pi_{i}^{R}$ as long as it can fully extract $\pi_{i}^{R}$ under $j^{R}$. In other words, prior to $j^{R}$, s transition to $j^{E}, i$ would be less inclined to adapt its business model if $\pi_{i}^{R}$ is larger. Henceforth, $i$ becomes to preserve a conservative attitude as larger the $\pi_{i}^{R}$ is.

Proposition 3. The higher (lower) the $\pi_{i}^{R E}\left(\pi_{i}^{R}\right)$ is, the higher the $\beta^{*}$ is. Between $\pi_{i}^{R E}$ and $\pi_{i}^{R}, \pi_{i, t}^{R E}$ has a larger impact on $\beta^{*}$ compared to $\pi_{i}^{R}$.

$$
\begin{gathered}
\text { Proof. Note that } \frac{\partial \beta^{*}}{\partial \pi_{i}^{R E}}=\frac{1}{2}\left(\frac{\pi_{i}^{R E}}{\pi_{i}^{R}}\right)^{-\frac{1}{2}} \frac{1}{\pi_{i, t}^{R}}>0 \text { and } \frac{\partial \beta^{*}}{\partial \pi_{i}^{R}}= \\
-\frac{1}{2}\left(\frac{\pi_{i}^{R E}}{\pi_{i}^{R}}\right)^{-\frac{1}{2}} \pi_{i}^{R E} \pi_{i, t}^{R}-2<0 .\left|\frac{\partial \beta^{*}}{\partial \pi_{i}^{R E}}\right|-\left|\frac{\partial \beta^{*}}{\partial \pi_{i}^{R}}\right|=\frac{1}{2}\left(\frac{\pi_{i}^{R E}}{\pi_{i}^{R}}\right)^{-\frac{1}{2}}\left[\frac{\pi_{i}^{R}-\pi_{i}^{R E}}{\left(\pi_{i}^{R}\right)^{2}}\right]<0 . \text { Q.E.D. }
\end{gathered}
$$

\subsection{Leapfrogging under Dynamics}

DOI: 10.24818/18423264/54.2.20.10 
A fundamental question associated with firm performance within a transition economy is whether $i$ can leapfrog incumbents in EU market. If there exists a chance for $i$ to leapfrog those incumbents, then $e x$-USSR countries would be inclined to transit toward free market system more aggressively. In fact, they would be willing to join into EU community. Now, an infinitely repeated game is considered. At $\mathrm{t}=1, i$ earns $\hat{\pi}_{i, t}^{R}$ under $j=j^{R}$ and it does $\delta \hat{\pi}_{i, t}^{R E}$ under $j=j^{R E}$ at $\mathrm{t}=2$. At $t=3, j$ transits to $j^{E}$ and so $i$ 's discounted profit for $t \geq 3$ is written into $\frac{\delta^{2}}{1-\delta} \hat{\pi}_{i, t}^{E}$ where $\delta=\frac{1}{1+r}$ is a discount factor and $r$ is a discount rate. The discounted net present value of $i$ 's profit under $j$ 's transition process is written into (6)

$$
\hat{Z}=\hat{\pi}_{i, t}^{R}+\delta \hat{\pi}_{i, t}^{R E}+\frac{\delta^{2}}{1-\delta} \hat{\pi}_{i, t}^{E}
$$

Proposition 4 clearly exhibits that those early transiting $e x$-USSR countries can have better opportunities to incubate competitive domestic firms quicker than those late transiting countries can. It is because the synergy effect described in Proposition 1 becomes to be expanded as earlier $j$ starts to transit to $j^{R E}$.

Proposition 4. $i$ can earn a higher discounted net present value as earlier $j$ transits to $j^{E}$. Also, the more the $i$ is patient, the higher the its discounted net present value is.

Proof. Consider that $j$ starts to transit from $t=4$, which is one-time lag behind to the case of (6). The discounted net present value of $i$ when $j$ starts to transit from $t=4$ is defined to be $\bar{Z}=\hat{\pi}_{i, t}^{R}+\delta \hat{\pi}_{i, t}^{R}+\delta^{2} \hat{\pi}_{i, t}^{R E}+\frac{\delta^{3}}{1-\delta} \hat{\pi}_{i, t}^{E}$. Note that $\hat{Z}-\bar{Z} \approx \delta \hat{\pi}_{i, t}^{R E}-\delta \hat{\pi}_{i, t}^{R}+\delta^{2} \hat{\pi}_{i, t}^{E}-\delta^{2} \hat{\pi}_{i, t}^{R E}$. As $\delta \rightarrow 1, \hat{Z}-\bar{Z}=\hat{\pi}_{i, t}^{E}-\hat{\pi}_{i, t}^{R}>0$ while $\hat{Z}-\bar{Z}=0$ as $\delta \rightarrow 0$.

Q.E.D.

Let the discounted net present value of an incumbent, i.e.m, in EU be $\tilde{Z}=$ $\frac{1}{1-\delta} \hat{\pi}_{m, t}^{E}$. For simplicity, it is assumed to be $\hat{\pi}_{i, t}^{E}=\hat{\pi}_{m, t}^{E}$. The likelihood for $i$ to leapfrog $m$ is arranged into (7).

$$
L=\hat{\pi}_{i, t}^{R}+\delta \hat{\pi}_{i, t}^{R E}+\frac{\delta^{2}}{1-\delta} \hat{\pi}_{i, t}^{E}-\frac{1}{1-\delta} \hat{\pi}_{m, t}^{E}
$$

By Proposition 5, $i$ is less likely to leapfrog EU firms as higher the $\alpha$ is but the opportunity cost paid under $j^{R}$ is a non-negligible factor for $i$ to grow rapidly. Fortunately, this negative effect can be overcome by the outside option that $i$ can enjoy as $j$ transits to $j^{E}$. With regard to this finding, it is interesting to state that $i$ 's chance for leapfrogging incumbents would be parallel to the economic cycle of EU region. For instance, $i$ can acquire a higher $\beta$ when EU economy expands and vice versa. 
Firm Performances within Transition Countries: Pro-EU Group vs. Pro-Russia Group

Proposition 5. $i$ under $j^{E}$ becomes to be more likely to leapfrog $m$ as higher the $\beta^{*}$ is; however, such chance decreases as higher the $\alpha$ is at the same time.

$$
\text { Proof. } \frac{\partial L}{\partial \alpha}=-1\left\{\hat{\pi}_{i, t}^{R}+\frac{\delta}{1+\beta} \hat{\pi}_{i, t}^{R E}\right\}<0 \text { and } \frac{\partial^{2} L}{\partial \alpha \partial \beta}=\frac{\delta}{(1+\beta)^{2}} \hat{\pi}_{i, t}^{R E}>0 \text {. Q.E.D. }
$$

\section{Empirical Framework}

\subsection{Dataset}

The dataset used in the paper is collected from "Business Environment and Enterprise Performance Survey", which is jointly constructed by World Bank and EBRD (European Bank for Reconstruction and Development) for the years of 2008, 2009, 2011, 2012, 2013, and 2014. "Environment and Enterprise Performance Survey" has limited information on firm strategic aspects as its main scope is to generalize cross-sectional country comparison and its diverse impact on firm performance. Particularly, firm performance measure is limited to sales and most questionnaires are survey based, which limits the applicability of the database. Nevertheless, the dataset contains some useful firm level activities as well as firm characteristics such as size, exports, and foundation year.

\subsection{Equations}

Equations (8) - (11) are estimated by pooling ordinary least squares and the dependent variable $y_{i, t}$ is the natural $\log$ of $i$ 's annual sales. A common notion about transition countries is that communism-based capitalism still prevails amongst transition countries; they would like to depend on EU economically but they are tied with Russia politically. Thus, (8) and (9) are designed to test two important things. First, it is under curiosity whether pro-EU group can comparatively earn more than pro-Russian group can. $j$ is a country dummy that gives the value of one to transition countries and $t$ is a year dummy for the years of $2008,2009,2011,2012,2013$, and 2014. $e_{d}$ is a pro-EU group dummy that gives the value of one to those countries classified as pro-EU group in Table 1 and a proRussia group dummyr $r_{d}$ is similarly defined.

Second, it is interesting to scrutinize if the degree of market openness enhanced the firm performance of transition countries indeed. Reflecting that transition countries, typically specialized into labor-intensive industries, mainly export commodities and natural resources, the volatility of the transition countries is expected to be higher, which can hurt their firm performances. Accordingly, one cannot easily presume that the firm performance of export-oriented transition countries dominates that of domestic-oriented ones. For testing this issue, two variables are used. The ratio of domestic sales over total sales, i.e.dri,t tell us if $i$ is a domestic-focused firm. In contrast, $e r_{i, t}$ is the ratio of total exports over total sales and so the higher the $e r_{i, t}$ is, the higher the degree of $i$ 's market openness. 
As explanatory variables, $o p_{i, t}$ represents market-know measured by $i$ 's total operation years since its initial foundation. $\mathrm{em}_{i, t}$ is $i$ 's total regular employees and it is a proxy for $i$ 's size. For correcting size effect, the square term $\left(e m_{i, t}^{2}\right)$ is used as well.

$$
\begin{aligned}
& y_{i, t}=c+j+t+e_{d}+r_{d}+d r_{i, t}+o p_{i, t}+e m_{i, t}+e m_{i, t}^{2}+\varepsilon_{i, t} \\
& y_{i, t}=c+j+t+e_{d}+r_{d}+e r_{i, t}+o p_{i, t}+e m_{i, t}+e m_{i, t}^{2}+\varepsilon_{i, t}
\end{aligned}
$$

(10) and (11) test which one between the manufacturing and service sectors contributes more to the performance of $i$ in $j . m_{d}$ is a dummy variable that gives the value of one to $i$ if it is located in a manufacturing sector while $s_{d}$ is a dummy variable that gives the value of one if $i$ is located in a service sector.

$$
\begin{aligned}
& y_{i, t}=c+j+t+m_{d}+s_{d}+d r_{i, t}+o p_{i, t}+e m_{i, t}+e m_{i, t}^{2}+\varepsilon_{i, t} \\
& y_{i, t}=c+j+t+m_{d}+s_{d}+e r_{i, t}+o p_{i, t}+e m_{i, t}+e m_{i, t}^{2}+\varepsilon_{i, t}
\end{aligned}
$$

It is worthwhile tackling if bureaucratic heritage affects firm performance amongst transition countries. At a glance, state-owned firms are expected to perform better in transition countries due to long-lasting bureaucratic heritage. However, the role of foreign aids programs cannot be overlooked as they are the main funding source for incubating privately owned corporations as well as startups while transplanting free market system into ex-USSR region.

In order to tackle this issue, (12) \& (13) are designed to explore the impact of organizational characteristics on $i$ 's performance. $p g_{d}$ is a dummy that gives the value of one to $i$ if it begins as a state-owned firm but transits to a private firm later. $p s_{d}$ is a startup dummy and $s g_{d}$ is a dummy when $i$ begins as a private subsidiary of a former state-owned firm. $j v_{d}$ is a joint venture dummy that gives the value of one to $i$ if it is jointly established with foreign investor(s). $g v_{d}$ is a state-owned firm dummy. Thus, the firm type dummies in (12) \& (13) can test which type of firms between privately established ones and state-owned ones can perform better.

In ex-communist countries, informal payment is frequently criticized for ingenerating society-wise corruption, which incurs the cost inefficiency of $i$. Therefore, how cost inefficiency, casually referred as one of main obstacles toi's performance, deteriorates $y_{i, t}$ should be analyzed too once it is attempted to analyze the impact of organizational characteristics on firm performance. In (12) \& (13), informal payment $\left(c r_{i, t}\right)$ is used as a proxy for measuring cost inefficiency.

$$
\begin{aligned}
& y_{i, t}= c+j+p g_{d}+p s_{d}+s g_{d}+j v_{d}+g v_{d}+c r_{i, t}+o p_{i, t}+e m_{i, t}+ \\
& e m_{i, t}^{2}+\varepsilon_{i, t} \\
& y_{i, t}= c+j+t+p g_{d}+p s_{d}+s g_{d}+j v_{d}+g v_{d}+c r_{i, t}+o p_{i, t}+ \\
& e m_{i, t}+e m_{i, t}^{2}+\varepsilon_{i, t}
\end{aligned}
$$

DOI: $10.24818 / 18423264 / 54.2 .20 .10$ 
Firm Performances within Transition Countries: Pro-EU Group vs. Pro-Russia Group

\section{Empirical Results}

Table 2 is designed to answer a generic question associated with the firm performance of transition countries. Those countries having close reciprocal ties with Russia show superior performances. This result implies three strategic points. First, it cannot be denied that social values are still put weight on communism heritage, and so barter trade is still an important vehicle for the economic distribution of the region. Second, weak property rights protection expands volatility amongst transition countries (Röhn et al., 2009), and thus firms in transition countries, as a whole group, are not that competitive enough to penetrate EU markets. Third, their performance can fade away if Russian economy shrinks down due to sanctions in 2014.

Next, between manufacturing and service sectors, the sales volume of the latter turns out to be greater. This result requires a careful interpretation. In that, one cannot easily conclude that the service sector of transition countries is more competitive than their manufacturing sector. Rather, the manufacturing sector of transition countries is less likely to be competent, and, as a result, the service sector of transition countries can dominate the firm performance of manufacturing sector.

The issue of market openness is still a controversial one (Haddad, et al., 2013) but, to the least, domestic-oriented firms turn out to perform better than export-oriented firms. This empirical finding suggests that, combined with weak manufacturing sector's firm performance, lower market openness results in the better firm performance of pro-Russia group.As long as the firm performance of transition countries is heavily dependent on commodity exports heading to Russia, they have no choice but to experience the Dutch disease that BenYishay\&Grosjean (2014) point out. Consequently, pro-Russian policies or bureaucratic domestic policies can still play important roles because $e x$-USSR heritages are shared within transition countries. For instance, Jackowicz et al. (2013) empirically demonstrates that state-owned banks in Central European countries become to record significantly lower net interest incomes because lower interest rates are charged on loans they make; surely, this banking policy is set to implement political goals to support domestic markets and so they are called as bureaucratic financial institutions.

In bureaucratic countries, higher ranked managers hold strong powers in decision making, which frequently results in non-productive outputs. This type of inefficiency incurs inferior firm performance. Also, lacking free competition mechanism, it is presumed that the more bureaucratic a country is, the older the large firms in the country are likely to be. Hence, one can argue that the older the firm's age is, the more inefficient it is likely to be. This prediction is consistent to the empirical findings in Table 2 because firm age is significantly and negatively related to firm sales. Size effect turns out to have significant effect but it is marginally decreasing, which in turn implicates that transition countries need to incubate private firms.

DOI: 10.24818/18423264/54.2.20.10 
HyungRokYim

Table 2. Pooling OLS: Firm Characteristics and their Contributions to Firm Sales

\begin{tabular}{|c|c|c|c|c|}
\hline Variables & Equation (8) & Equation (9) & Equation (10) & Equation (11) \\
\hline$c$ & $\begin{array}{c}7.2154 \\
(0.4791)\end{array}$ & $\begin{array}{c}7.7106 \\
(0.4742)\end{array}$ & $\begin{array}{l}10.1150 \\
(0.4511)\end{array}$ & $\begin{array}{l}10.0748 \\
(0.4486)\end{array}$ \\
\hline$e_{d}$ & $\begin{array}{l}0.5835^{*} \\
(0.0745)\end{array}$ & $\begin{array}{l}0.5835^{*} \\
(0.0745)\end{array}$ & - & - \\
\hline$r_{d}$ & $\begin{array}{l}1.2986^{*} \\
(0.0775)\end{array}$ & $\begin{array}{l}1.2986^{*} \\
(0.0775)\end{array}$ & - & - \\
\hline$m_{d}$ & - & - & $\begin{array}{c}-0.5854 * * \\
(0.0408)\end{array}$ & $\begin{array}{c}-0.5582 * * \\
(0.0410)\end{array}$ \\
\hline$s_{d}$ & - & - & $\begin{array}{c}0.1613 * * \\
(0.0475)\end{array}$ & $\begin{array}{c}0.1524 * * \\
(0.0475)\end{array}$ \\
\hline$d r_{i, t}$ & $\begin{array}{l}0.4952 * \\
(0.0692)\end{array}$ & - & $\begin{array}{l}-0.2339 * \\
(0.0809)\end{array}$ & - \\
\hline$e r_{i, t}$ & - & $\begin{array}{l}-0.4952^{*} \\
(0.0692)\end{array}$ & - & $\begin{array}{l}-0.4081 * \\
(0.0704)\end{array}$ \\
\hline$o p_{i, t}$ & $\begin{array}{c}-0.1305 * * \\
(0.0423)\end{array}$ & $\begin{array}{c}-0.1305 * * \\
(0.0423)\end{array}$ & $\begin{array}{c}-0.2280 * * \\
(0.0421)\end{array}$ & $\begin{array}{c}-0.2296 * * \\
(0.0420)\end{array}$ \\
\hline$e m_{i, t}$ & $\begin{array}{l}1.1354 * \\
(0.0559)\end{array}$ & $\begin{array}{l}1.1354^{*} \\
(0.0559)\end{array}$ & $\begin{array}{l}1.2884 * \\
(0.0565)\end{array}$ & $\begin{array}{l}1.3049 * \\
(0.0566)\end{array}$ \\
\hline$e m_{i, t}^{2}$ & $\begin{array}{c}-0.0002 * * * * \\
(0.0073)\end{array}$ & $\begin{array}{c}-0.0002 * * * \\
(0.0073)\end{array}$ & $\begin{array}{c}-0.0132 * * * \\
(0.0074)\end{array}$ & $\begin{array}{c}-0.0144 * * * \\
(0.0074)\end{array}$ \\
\hline $\begin{array}{l}R^{2} \\
\text { Obs. }\end{array}$ & $\begin{array}{c}0.3088 \\
21399\end{array}$ & $\begin{array}{l}0.3088 \\
21399\end{array}$ & $\begin{array}{l}0.3037 \\
21381\end{array}$ & $\begin{array}{l}0.3051 \\
21399\end{array}$ \\
\hline
\end{tabular}

1. The numbers in the parentheses are standard errors.

2. *, $* *$, and $* * *$ are significant at $90 \%, 95 \%$, and $99 \%$ level.

3. Year dummies are not reported.

Table 3 explores which type of firms in transition countries can show higher performances. Joint ventures are actively pursued in transition countries first because foreign partners, mostly from west European region, can lessen the liability of foreignness and second because their capital, mixed with cheap labor forces, can create synergy effects both to original investors and local host partners.

In Table 3, those firms established through joint venture with foreign partner(s) can achieve the highest sales performances because synergy effects created by both the efficient resource allocation management and production technique of foreign partners can expand joint ventures' marketability. In contrast, state-owned firms do not earn more than those privately established firms, which implies that bureaucratic indolence still prevails over state-owned firms. In contrast, startups show significant and positive firm performances and those private subsidiaries of former state-owned firms show efficient performances as well. Therefore, once transition countries' governments are intended to develop their 
Firm Performances within Transition Countries: Pro-EU Group vs. Pro-Russia Group

economies, it is essential to adopt pro-market policy. By group-wise comparison, state-owned firms in pro-EU economies cannot perform better than other types, which is an exactly opposite result against state-owned firms in pro-Russian economies. This implies that governmental-wise mutual interaction with Russia still plays a more important role in the firm performance of the group.

The degree of informal payment practice is a proxy variable to measure the cost inefficiency amongst firms in transition countries. It shows negative coefficients; Informal payment turns out to be significantly negative to firm performance among pro-EU group whilst it is not in pro-Russia group.

Table 3. Pooling OLS: The Effect of Firm Type on Firm Performance

\begin{tabular}{|c|c|c|c|c|}
\hline Variables & $\begin{array}{c}\text { Eq. (12) } \\
\text { : Both Groups }\end{array}$ & $\begin{array}{c}\text { Eq. (13) } \\
\text { : Both Groups }\end{array}$ & $\begin{array}{l}\text { Eq. (12) } \\
\text { : pro-EU } \\
\text { Group }\end{array}$ & $\begin{array}{c}\text { Eq. (13) } \\
\text { : pro-Russia } \\
\text { Group }\end{array}$ \\
\hline$c$ & $\begin{array}{c}10.3505 * * * \\
(0.1894)\end{array}$ & $\begin{array}{c}8.5527 * * * \\
(0.5829)\end{array}$ & $\begin{array}{l}941.7620 \text { ** } \\
(373.4204)\end{array}$ & $\begin{array}{c}11.8656 * * * \\
(0.6292)\end{array}$ \\
\hline$p g_{d}$ & $\begin{array}{l}-0.0209 \\
(0.1308)\end{array}$ & $\begin{array}{l}-0.0043 \\
(0.1299)\end{array}$ & $\begin{array}{l}-0.1815 \\
(0.2257)\end{array}$ & $\begin{array}{c}0.1768 \\
(0.1275)\end{array}$ \\
\hline$p s_{d}$ & $\begin{array}{c}0.2461 * * \\
(0.1256)\end{array}$ & $\begin{array}{c}0.2556 * * \\
(0.1247)\end{array}$ & $\begin{array}{c}0.0088 \\
(0.2065)\end{array}$ & $\begin{array}{c}0.4822 * * * \\
(0.1209)\end{array}$ \\
\hline$s g_{d}$ & $\begin{array}{l}0.2509 * \\
(0.1521)\end{array}$ & $\begin{array}{l}0.2639 * \\
(0.1513)\end{array}$ & $\begin{array}{l}-0.1073 \\
(0.2980)\end{array}$ & $\begin{array}{c}0.5041 * * * \\
(0.1550)\end{array}$ \\
\hline$j v_{d}$ & $\begin{array}{c}0.6055 * * * \\
(0.1810)\end{array}$ & $\begin{array}{c}0.6137 * * * \\
(0.1803)\end{array}$ & $\begin{array}{c}0.4491 \\
(0.4374)\end{array}$ & $\begin{array}{c}0.8304 * * * \\
(0.1659)\end{array}$ \\
\hline$g v_{d}$ & $\begin{array}{c}0.0491 \\
(0.1811)\end{array}$ & $\begin{array}{c}0.0576 \\
(0.1804)\end{array}$ & $\begin{array}{l}-0.8801 * \\
(0.4505)\end{array}$ & $\begin{array}{l}0.4190 * * \\
(0.1776)\end{array}$ \\
\hline$c r_{i, t}$ & $\begin{array}{c}-0.0093 * * * \\
(0.0026)\end{array}$ & $\begin{array}{c}-0.0082 * * * \\
(0.0027)\end{array}$ & $\begin{array}{c}-0.0123^{* *} \\
(0.0050)\end{array}$ & $\begin{array}{l}-0.0008 \\
(0.0030)\end{array}$ \\
\hline$o p_{i, t}$ & $\begin{array}{l}-0.0083 \\
(0.0342)\end{array}$ & $\begin{array}{c}-0.0140 * * \\
(0.0343)\end{array}$ & $\begin{array}{c}0.0397 \\
(0.0597)\end{array}$ & $\begin{array}{c}-0.0521 * * \\
(0.0423)\end{array}$ \\
\hline$e m_{i, t}$ & $\begin{array}{l}1.0232 * * \\
(0.0439)\end{array}$ & $\begin{array}{l}1.0204 * * \\
(0.0440)\end{array}$ & $\begin{array}{c}1.0840 * * * \\
(0.0744)\end{array}$ & $\begin{array}{c}0.9409 * * * \\
(0.0541)\end{array}$ \\
\hline$e m_{i, t}^{2}$ & $\begin{array}{l}-0.0008 \\
(0.0060)\end{array}$ & $\begin{array}{c}-0.0003 * * * \\
(0.0060)\end{array}$ & $\begin{array}{l}-0.0136 \\
(0.0103)\end{array}$ & $\begin{array}{l}0.0128^{*} \\
(0.0072)\end{array}$ \\
\hline $\begin{array}{c}R^{2} \\
\text { Obs. }\end{array}$ & $\begin{array}{l}0.7602 \\
13,027\end{array}$ & $\begin{array}{l}0.7606 \\
13,027\end{array}$ & $\begin{array}{c}0.6415 \\
5,025\end{array}$ & $\begin{array}{c}0.8050 \\
7,423\end{array}$ \\
\hline
\end{tabular}

1. The numbers in the parentheses are standard errors.

2. *,**, and *** are significant at $10 \%, 5 \%$, and $1 \%$ level.

3 . Year and country dummies are not reported.

DOI: 10.24818/18423264/54.2.20.10 
HyungRokYim

\section{Conclusion}

Four interesting predictions were earned through the theoretic model of the paper. First, keeping strong mutual tie with Russia is a rational choice; transition countries are fundamentally motivated to maintain business relationship with Russia not because they are ex-USSR countries but because pro-Russian businesses are traditionally cash-cows. For instance, exports to Russia are focused on primary industries like mineral, food, raw materials, and consumption goods. Second, because pro-European businesses are rising stars, firms in pro-EU group can approach EU market as a way of diversification. Adversely speaking, unless EU market provides enough profits, firms in transition countries would rely on traditional partnership with Russian firms rather than taking business risks in competitive EU market. Third, firms in transition countries can leapfrog incumbents in EU if their home countries transit to pro-EU group.

Empirical results were summarized into the followings. First, between proEU group and pro-Russia group, firms in the latter show better performances. This is a contradicting result against Uzagalieva, et al (2012) who exhibits that inbound FDIs from EU enhance the firm performance of transition countries. The reason for this outcome can be sought in two directions. According to Hanousek, et al. (2011), spillover effects through inbound FDIs in downstream sectors are frequently negative; those transition countries, heavily dependent on primary industries, could not create spillover effects in the region. Next, ex-USSR networking mechanism still plays an important role in determining firm performances across transition countries. Combined with the predictions of the model, one can say that reinforcing interactions with EU should be understood as a conditional event on the conservative attitude of transition countries toward Russia. Second, informal payment significantly deteriorates the firm performance of proEU group whilst it does not that of pro-Russia group. Third, in transition countries, domestic-oriented firms perform better than export-oriented firms. Fourth, combined with the finding that privately established firms perform better in transition countries, the negative effect of firm age on firm performance implies that younger private firms are more efficient. Therefore, it is not too much say that those transition countries with active entrepreneurship are the ones that can easily overcome ex-communism oriented bureaucratism and cost inefficiency.

\section{REFERENCES}

[1] Campos, N. F. \&Coricelli, A. (2002), Growth in Transition: What We Know, What We Don't, and What We Should.Journal of economic literature, 40(3), 793836;

[2] Damijan, J. P., Knell, M.,Majcen, B. \&Rojec, M. (2003), The Role of FDI, $R \& D$ Accumulation and Trade in Transferring Technology to Transition Countries: Evidence from Firm Panel Data for Eight Transition Countries.Economic systems, 27(2), 189-204;

DOI: $10.24818 / 18423264 / 54.2 .20 .10$ 
Firm Performances within Transition Countries: Pro-EU Group vs. Pro-Russia Group

[3] Uzagalieva, A., Kočenda, E. \&Menezes, A. (2012), Technological Innovation in New EU Markets. Emerging Markets Finance and Trade, 48(5), 48-65;

[4] Kamau, N. L. (2010), The Impact of Regional Integration on Economic Growth: Empirical Evidence from COMESA, EAC and SADC Trade Blocs. American Journal of Social and Management Sciences, 1(2), 150-163;

[5] Campos, N. F.\&Horváth, R. (2012), Reform Redux: Measurement, Determinants and Growth Implications. European Journal of Political Economy, 28(2), 227-237;

[6] Brunnschweiler, C. N. \&Bulte, E. H. (2008), The Resource Curse Revisited and Revised: A Tale of Paradoxes and Red Herrings. Journal of environmental economics and management, 55(3), 248-264;

[7] Bandick, R. \&Karpaty, P. (2011),Employment Effects of Foreign Acquisition. International Review of Economics \& Finance, 20(2), 211-224; [8] Djalilov, K. \&Piesse, J. (2019), Bank Regulation and Efficiency: Evidence from Transition Countries. International Review of Economics \& Finance, 64, 308-322;

[9] Artis, M. J.\&Fidrmuc, J., \&Scharler, J. (2008), The Transmission of Business Cycles Implications for EMU Enlargement.Economics of Transformation and Institutional Change, 16(3), 559-582;

[10] Corden, W. M. \&Neary, J. P. (1982), Booming Sector and DeIndustrialisation in a Small Open Economy. The economic journal, 92(368), 825-848;

[11] White, C. \&Imre, I. (2013), Acceptance of Democracy and Public Relations: Attitudes in a Transitional Country. Public Relations Review, 39(4), 394-397;

[12] Röhn, O., Orazbayev, S. \&Sarinzhipov, A. (2009), An Institutional Risk Analysis of the Kazakh Economy (No. 70). Ifo Working Paper;

[13] Haddad, M., Lim, J. J., Pancaro, C. \&Saborowski, C. (2013), Trade Openness Reduces Growth Volatility when Countries are well Diversified. Canadian Journal of Economics/Revue canadienned'économique, 46(2), 765-790; [14] BenYishay, A. \&Grosjean, P. (2014), Initial Endowments and Economic Reform in 27 Post-socialist Countries. Journal of Comparative Economics, 42(4), 892-906;

[15]Jackowicz, K., Kowalewski, O.\&Kozłowski, L. (2013), The Influence of Political Factors on Commercial Banks in Central European Countries.Journal of Financial Stability, 9(4), 759-777;

[16]Hanousek, J., Kočenda, E. \&Maurel, M. (2011), Direct and Indirect Effects of FDI in Emerging European Markets: A Survey and Meta-Analysis. Economic Systems, 35(3)2011, 301-322.

DOI: $10.24818 / 18423264 / 54.2 .20 .10$ 